\title{
ENGAGEMENT OF THE MINISTRY OF DEFENSE AND BULGARIAN ARMED FORCES IN ESTABLISHING INFORMATION SOCIETY
}

\author{
Vladimir GRIGOROV
}

\section{Introduction}

The transition to Information Society (IS) has no alternative. The question of national concern, that we face now, is not whether IS should be established, but rather what are the best ways to do it. The transition to IS is an international, transcontinental process, in which separate countries carry out their national policies.

With the Decree \# 679 of 29 October 1999 the Council of Ministers adopted a Strategy for Development of Information Society in the Republic of Bulgaria ${ }^{1}$ and a National Program for the Development of Information Society. ${ }^{2}$ With this Decree the Bulgarian Government clearly showed its understanding of the importance of IS in almost all spheres of our administrative and political life.

The new strategic vision of the MoD authorities, as part of the Bulgarian Government, is oriented towards utilizing military formations in an international environment, participation in operations other than war and their application to prevent any potential threat to the national security. The significance of the technological innovation and the challenges of establishing IS receive adequate treatment in a number of both academic studies ${ }^{3}$ and main security and defense policy documents. ${ }^{4,5}$ The awareness that information dominance is a prerequisite for realizing new operational concepts and achieving synergetic effect from the integral utilization of military power in all types of military operations is becoming more profound. $^{3,5}$

In the past few years, the issue of the Information Society (IS) established itself worldwide as one of the main topics on high-level political forums. The Information Society development poses before governments a number of complex issues related to various fields of public life and requiring coordinated action. In Bulgaria, by 
Decree \# 40 of 1998, the Council of Ministers established Coordination Council on Information Society Issues. Its basic function is "to develop and submit for approval by the Council of Ministers the strategy and the national program for the Information Society development in the Republic of Bulgaria."

\section{Strategy and National Program for Development of IS}

The challenge of preparing a strategy for the Information Society stems from the short time and its great scope - the IS issues concern all sectors of public and economic life. At the same time, the activities for the transition to Information Society are seen as vitally important for the Bulgarian integration into the European Union. The Strategy for Information Society development in the Republic of Bulgaria defines national priorities for transition to IS at legislative, technological, economic and social levels and outlines main related activities. The document combines the IS concept of the European Union with the national interests and the specific realities of our country, thus focusing on:

- consolidation of the democratic system;

- preparation for European and Euro-Atlantic integration;

- market economy development;

- functioning of the Currency board.

The document is developed in conformity with the Governmental Program "Bulgaria 2001" and takes into account related documents of ministries and other state agencies. Representatives of the Bulgarian Institute of Legal Development, Bulgarian Academy of Sciences, Bulgarian Telecommunications Company, National Chamber of Business Development, and the Information Society Development Association were involved in its preparation. The document takes into account the European Union strategy, national strategies and programs for transition to IS of developed countries and related documents of a number of European countries. Political and legal documents of the European Union, the Council of Europe and other international organizations were thoroughly studied, too.

Based on the Strategy, National Program for the Information Society development in the country was developed. State organizations are also preparing strategies and programs, outlining goals and intentions for the transition to the Information Society related to the sector they cover. The document "Strategy of the Information Society Development in the Republic of Bulgaria" is periodically updated and amended in accordance with developments at international and national level.

The Information Society appears as result of the changes caused by the massive introduction of new information and communications technologies (ICT). As stated in 
Decree \# 40 of the Council of Ministers, "the Information Society is a society with qualitatively new structure, organization and public relations, based on global access and usage of information and communications networks and services free of national, geographic or any other restrictions, for exchange of information, scientific, intellectual, cultural and other achievements." Accordingly, basic characteristics of IS are:

- utilization of information and communications technologies in all economic and social activities;

- de-massification of social and economical processes ${ }^{6}$ - small-series $^{-}$ production, market segmentation, disintegration of some of the big industrial companies, etc.;

- $\quad$ high employment in the area of services - over 50 percent of the whole working population;

- continuous process of qualification in dynamically changing environment requiring lifelong learning and self-education;

- enhancement of the social role of the individual - the changes in the nature of labor and management enhance the individual's responsibility;

- globalization, economic and social cohesion - conditions are created for building a "society without frontiers," for elimination of "distances," for transition towards social uniformity.

The transition to IS has no alternative. A matter of national choice is not whether IS will be built, but what are the best methods and forms for its realization. The transition to IS is a trans-border and transnational process in which the states pursue their particular national policies.

In recent years, the technologically developed countries like the United States, EU member-states, etc., adopted strategies and programs for transition to the Information Society. Such documents are prepared by almost all countries of Central and Eastern Europe (Romania, Estonia, Hungary, Slovenia, Latvia, Lithuania, etc.). These acts outline the integrated framework for IS and encompass key sectors, such as telecommunications, scientific research and development, innovations, competitiveness, small and medium enterprises, economic and social cohesion, intellectual property, data protection, electronic commerce, international relations and cultural exchange.

Globally, the following core principles of the policy for IS development are set forth:

- $\quad$ promoting competition;

- encouraging private investments;

- defining an adaptable regulatory framework; 
- $\quad$ providing open access to networks;

- ensuring universal information services;

- promoting equal rights of access to information resources;

- promoting diversity of content, including preservation of cultural and linguistic diversity;

- recognizing the necessity of worldwide cooperation with particular attention to less developed countries.

While establishing the IS, Bulgaria has to find an adequate national expression of these principles.

In view of the global trends of the Information Society development and the Bulgarian conditions, the basic goals that have to be achieved in the process of transition to IS in Bulgaria are:

- preparation and adoption of a complete legal framework, rules and procedures, harmonized with those of the European Union, for provision of services, for living and working in the Information Society;

- ensuring equal access for all citizens to modern, efficient and high-quality telecommunications and information services, as well as equal opportunities for acquiring skills for their utilization;

- creation of new living and working environment through wide use of new ICT in the public, political, economic and cultural sphere.

In order to achieve the goals for transition to IS, the following action should be undertaken:

- introduction of European norms of ensuring access to information while guaranteeing data security and basic human rights;

- creation of a transparent and predictable legal and regulatory framework for provision of Information Society services to the population and businesses;

- getting the national standardization system in conformity with the international requirements;

- development and modernization of the telecommunications infrastructure as a basis for building the national information infrastructure;

- provision of telecommunications, media, multimedia and information services in a liberalized environment, with clear mechanisms for respecting the rights of citizens and consumers; 
- introduction of modern ICT in management, economy, education, culture, health care, national security, ecology;

- updating the functions, structure, products and services of administration and business in accordance with the new ICT and creation of conditions for sustainable development;

- development of information, communication and audiovisual/multimedia industry based on the principle of non-discrimination and fair competition;

- ensuring conditions for common education, continuous and individualized ICT training;

- training highly qualified ICT specialists;

- establishment of the necessary conditions for complete use of the opportunities for employment in IS;

- utilization of the new ICT for preservation of national traditions, culture and identity;

- wide awareness and preparation of the society for complete realization within IS.

\section{Contribution of the Ministry of Defense}

The responsibility for realizing this strategy lies with the Coordination Council on Information Society Issues. This specialized body to the Council of Ministers takes decisions at national level. It monitors and coordinates the mutual interests, needs and activities of the state bodies aimed at realization of the goals and tasks included in the Strategy and in the National Program.

The Ministry of Defense is represented at the Coordination Council on Information Society Issues by the Deputy Minister on Defense Policy and Planning and the Deputy Chief of General Staff (GS) on operations. The Deputy CIO (Chief Information Officer) assists the permanent working group of the Coordination Council. IT specialists from the MoD and armed forces participate in various work groups that assist the Coordination Council.

As a result of the effort of the MoD representatives in the Coordination Council the following points were added to the list of recommendations for the operation of the Council in 2001:

- Institutionalization of the position of "Chief Information Officer" in structures of the state administration.

- Development of regulations for implementation of information and communications systems of the state administration. 
- Development of information assurance concept for the needs of the defense and security.

The Coordination Council is assisted by the Committee of Posts and Telecommunications (CPT) that conducts operational coordination with ministries and state bodies, with representatives of public organizations and institutions and with the private sector. As a state body in charge of the administration and technical support of the Coordination Council, CPT monitors, analyses and disseminates information regarding the current state and trends at international and national level with respect to IS development, organizes and coordinates national events and the participation in international forums on issues of IS.

In the particular sectors, the authorized state bodies manage and monitor the implementation of the goals and tasks, stemming from the Strategy and the National Program for IS development. They periodically inform the Coordination Council on the development in the sector, problems and need of assistance.

The new ICT also offer opportunities for more efficient communications and exchange with the European institutions in the process of Bulgaria's preparation for joining the EU. For these reasons, specialized databases will be created, reflecting the institutions' activities on the country's preparation for membership. Furthermore, efficient telematic links with relevant institutions of the EU will be built.

As a whole, the development of the IS is expected to contribute to the harmonization of the relations between administration, population and business and to strengthening of the democratic public control over the management of the country.

Defense management and strengthening the national security play a key role in the establishment of the IS in the country. It is necessary to apply consistently the principles of transparency of management and civil control of the military, on one hand, and guaranteeing the necessary degree of secrecy, on the other.

Bulgaria's integration in NATO demands modern and efficient armed forces, adequately equipped with information and communications systems. Priority tasks in this respect are:

- Modernization of the system for command, control, communications, information and surveillance systems in the Ministry of Defense through:

- building a system for command, control, communications, information and surveillance systems in the Ministry of Defense totally compatible both internally, and with the national communication-information systems, as well as with NATO partners; 
- implementation of advanced communications and information technologies, meeting NATO standards, in order to provide information superiority, as set forth in the Bulgarian military doctrine;

- consistent application of the program approach and the team principle in building the systems for command, control, communications, information and surveillance systems in the Ministry of Defense;

- ensuring reliable protection mechanisms for accessing and using information in the military communications-information systems.

- Modernization of military education and defense research through:

- extension of the scope and updating of the educational programs in the field of ICT, in order to ensure adequate training of the command staff of the Bulgarian armed forces;

- introduction of modern multimedia products and virtual simulators for training the staff of the Bulgarian armed forces;

- introduction of ICT in the research and development activity in order to raise their efficiency and quality;

- introduction of a new system for scientific and applied studies through assignment of tasks, joint development, etc.

The development and modernization of communication and information systems (CIS), as an essential element of the management information system of MoD and Bulgarian Armed Forces (BAF), is vitally important for the completion of the tasks outlined in the reform plan, known as "Plan 2004", and the Membership Action Plan. The 1999 survey of C4 systems of the BA defined the major recommendations for the development of CIS, supporting the creation of realistic plans for procurement of a fully compliant functionality, reliability and operational compatibility. The amount of work, short deadlines and limited budget resources required the creation of an organizational structure with clearly outlined competence, responsibilities and management methods. For this purpose, a normative foundation was laid, containing the following documents:

1. C4 study recommendations ${ }^{7}$;

2. Manual for C4I Life Cycle Management in the Ministry of Defense and the Bulgarian Armed Forces ${ }^{8}$;

3. Concept for Planning, Programming and Budgeting and Manual for programming in the Ministry of Defense. ${ }^{9}$

The Manual for C4I Life Cycle Management defines conditions, rules and responsibilities of the bodies and authorities in the MoD and BAF that relate to ordering, planning, research and development activities, procurement, financing, 
exploitation and decommissioning of command and control systems, communications and information and intelligence systems (C4I). The Manual applies to all subsystems and software products, providing management and oversight of the basic C4I systems of MoD and BAF in both peace and crisis.

The next step, carried out in this direction, was the establishment of the institution "Chief Information Officer" (CIO) within MoD and BAF. Our decision was driven by the need to provide expert coordination and management of C4I systems projects from the start of the project to the beginning of system exploitation. The inauguration of $\mathrm{CIO}$ is not just an act of delegating responsibilities to the management of information technologies, but rather demonstrates the desire of MoD authorities to face the latest challenges. For example, in the United States training employees for this institution is considered a very important strategic goal. For the purposes of the US Department of Defense there is a college where future experts are educated in the field of information resource management.

The Manual for C4I Life Cycle Management and the CIO institution were introduced in MoD and BAF in June 2000 with an order of the Minister of Defense. The MoD successfully dealt with issues concerning C4I systems as well as with defense planning and programming. We are fully aware that a basic prerequisite for the success in this field are the clearly defined interrelations between:

- resources and results,

- participants and deadlines,

- constant monitoring, control and transparency of all expenses.

The development of C4I systems is realized through programs, subprograms and program modules (referred to herein as "programs") classified according to their type and level and incorporated in the "Program Decision Memorandum" of Ministry of Defense. The programs contain integrated $\mathrm{R} \& \mathrm{D}$, technological, technical, organizational and economic activities that contribute to the achievement of goals related to national security and development of modern C4I systems for the MoD and BAF. Subprograms and program modules are the separate parts of a program, financed within the main program.

The programs can be classified in three level groups, according to their significance for the defense of the Republic of Bulgaria, as follows: national level, departmental level and type of armed forces level.

The programs on the national level are designed to satisfy the needs of the Republic of Bulgaria in terms of the general requirements of $\mathrm{MoD}$ and $\mathrm{BAF}$ and other departmental and state organizations such as Ministry of Interior, Ministry of Transportation and Communications, etc. Their realization requires considerable 
financial resources and has direct impact on the national security. The programs on the departmental level are designed to satisfy MoD and BAF requirements for modern C4I systems and relevant technical and training facilities. Their realization influences directly the readiness of BAF to perform military operations. Currently, the programs on service level are designed to solve specific problems in the field of preservation, technical exploitation and maintenance of C4I systems in the respective formations.

Another essential point in our future activities is the decision to form integrated project groups consisting of experts from all departments, involved in their respective projects. The latter has already been planned for the following priority projects ${ }^{10}$ : Pilot Project for construction of communicational-information system in Sofia Garrison, the project for National Military Command Center, Air Sovereignty Operational Center (ASOC), the Field Communications and Information System (FICIS) for PSO designated units, teleconferencing project (DAMA SATCOM) and secure data interchange between the capitals of NATO member countries. The realization of these projects will give the necessary technological and organizational impetus to the modernization of C4I systems, thus turning them into the backbone of a future expanded system.

In compliance with Plan 2004, for the purposes of consolidating the scientific research and development activities, an Institute for Advanced Defense Research (IADR) was established in the "G.S. Rakovski" Defense College. IADR performs scientific research in the field of national security, defense and military forces. The three main areas of research are in defense resource management, C4I systems, and armaments. The IT research and development activities of the IADR are focused in the following areas:

- Advanced communications technologies;

- Information security;

- Geographical information systems;

- Modeling and simulation;

- Multimedia applications;

- Information support for defense resource management.

IADR performs its activities in close cooperation with partner scientific and research institutes, as well as with other national and foreign institutes through ${ }^{11}$ :

- Participation in joint working groups engaged in scientific programs, projects, studies, etc;

- Exchange of experts; 
- Participation in conferences, symposia, seminars, etc., related to IADR field of activities;

- Education and training;

- Specialized training and certification of IT specialists and users.

Memorandum for cooperative activities has been signed with the Bulgarian Academy of Science. Several research projects are performed jointly with high-tech business companies:

- with Cisco Systems Bulgaria - the establishment of Cisco Academy in the "G.S. Rakovski" Defense College;

- with S\&T and "Baltimore" - development of a pilot model, PKI (Public Key Infrastructure) and joint research activities in the field of information security;

- with Computer Associates Plc.-Bulgaria - testing network management solutions;

- with InfoGuard Ltd. - Bulgaria - testing wireless communications systems, anti-virus protection and maintenance of workflow management systems;

- with "GIS Invest" - research and testing applications for geographical information systems;

- With IDG-Bulgaria - testing and evaluating new technological solutions.

The Bulgarian defense establishment is an active contributor to national efforts towards development of the information society. We believe that by introducing modern normative base and institutions, the Bulgarian Ministry of Defense and General Staff will be able to respond adequately to the challenges of the Information Society. In certain cases, the Ministry of Defense may serve as "national testbed" for new organizational schemes and management practices in the area of IT development, thus leading technological and cultural advancement.

\section{References:}

1. Strategy for Development of Information Society in the Republic of Bulgaria (Sofia: Impulse Information Publishing Center, Ministry of Transportation and Communications, 1999). Available in English at http://www.cpt.bg/en/cpt/default.htm. 
2. National Program for Development of Information Society (Sofia: Impulse Information Publishing Center, Ministry of Transportation and Communications, 1999). Available in English at http://www.cpt.bg/en/cpt/default.htm.

3. See for example Velizar Shalamanov and Todor Tagarev, Information Aspects of Security (Sofia: Procon, 1996).

4. National Security Concept of the Republic of Bulgaria, State Newspaper, \# 46, 22 April 1998 (available full text in English at http://www.md.government.bg).

5. Military Doctrine of the Republic of Bulgaria, Approved by the XXXVIII National Assembly of the Republic of Bulgaria on April 8, 1999 (available full text in English at http://www.md.government.bg).

6. See for example, Alvin Toffler and Heidi Toffler, War and Anti-war: Survival at the Dawn of the $21^{\text {st }}$ century (Boston: Little, Brown and Co., 1993), 72.

7. See Command, Control, Communications and Computers Study for Bulgaria (Hanscom AFB, MA: Electronic Systems Center/MITRE, 2000); Main Recommendations for Development of C4I Systems in the Bulgarian Armed Forces (Sofia: Ministry of Defense, 2000).

8. Manual for C4I Life Cycle Management in the Ministry of Defense and the Bulgarian Armed Forces (Sofia: Military Publishing House, 2000).

9. Concept for Planning, Programming and Budgeting in the Ministry of Defense and the Armed Forces; Manual for Developing Programs in the Ministry of Defense and the Armed Forces (Sofia: Military Publishing House, 2000).

10. To be described in detail in the next volume of this journal.

11. "Research and Demonstration Center of the Institute for Advanced Defense Research," Information \& Security. An International Journal 4 (2000), 143.

VLADIMIR GRIGOROV is Chief of "Programs for Development of Armaments, Equipment, and Infrastructure" section of the Defense Planning Directorate in the Bulgarian Ministry of Defense. He was born on 22 of June 1955 in Sungurlare, Bulgaria. Mr. Grigorov holds a Bachelor Degree in Information Technologies from the Military Artillery and Air Defense School, Shumen, Bulgaria, and M.Sc. Degree in Management and Development of Information Systems from the National Defense College. Until 1999, Mr. Grigorov worked in the General Staff of the Bulgarian Armed Forces in the area of Communication and Information systems management. Since 2000, he is Deputy Chief Information Officer of the Bulgarian Ministry of Defense and a member of the permanent working group to the Coordination Council on Information Society Issues. 